\title{
A busca e o futuro da Internet
}

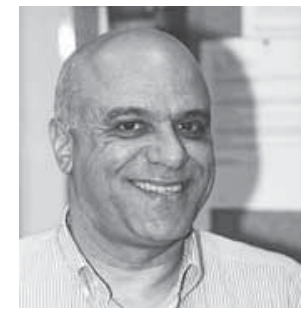

Eduardo H. Diniz FGVEAESP

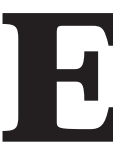

m seu livro A busca: como o Google e seus competidores reinventaram os negócios e estão transformando as nossas vidas, o jornalista e fundador da revista W ired, John Battelle, vai muito além de apenas contar a história do Google.

Naturalmente, há assunto de sobra para quem quer saber mais sobre as origens dessa empresa, que com poucos anos de vida já se tornou uma das empresas mais impressionantes do mundo da tecnologia. Muito mais interessantes, porém, são suas digressões sobre como uma atividade hoje tão banal quanto a de "fazer uma busca na Internet" transformou o que entendíamos por comércio eletrônico, e também como essa atividade está ajudando a desenhar o futuro da própria Internet.

Vamos tomar um exemplo. Imagine al guém desejando comprar uma garrafa de vinho; suponha que essa pessoa esteja em um supermercado e, antes de comprar o vinho de sua preferência, acesse uma ferramenta de busca (talvez o próprio Google) a partir de seu telefone celular. Por fim, considere que, depois de utilizá-lo para fazer a leitura do chip instalado no rótulo da garrafa, essa mesma pessoa faça uma consulta e descubra que, na vizinhança, outros supermercados estão vendendo o mesmo vinho a preços bem mais atraentes.

Obviamente, para que isso aconteça algumas mudanças importantes devem ser incorporadas à Internet atual. Primeira: a codi- ficação utilizada no rótulo da garrafa deverá ser disponibilizada ao público em geral. Segunda: os supermercados deverão tornar todo o seu estoque aberto e consultável pela Web. Em terceiro lugar, os celulares devem estar adaptados, tanto para a leitura das informações do rótulo, quanto para a consulta à Web. Seria ainda necessário que a ferramenta de busca reunisse todas essas informações e, por meio de aplicativos bem desenhados e "amigáveis", as organizasse para os internautas em geral.

À primeira vista, talvez isso pareça de difícil realização; contudo, várias dessas iniciativas já estão em andamento. Por exemplo, o projeto da Web 2.0, que pode ser entendido como a participação ativa dos usuários na criação de conteúdos para a Web, pode dar conta da primeira mudança. A segunda mudança vai depender de algum supermercado pioneiro começar a abrir as suas listas de produtos, provocando uma nova mudança de comportamento entre os seus concorrentes.

Quanto aos telefones celulares, bastaria acrescentar mais algumas destas funcionalidades. Na prática, o mais difícil seria a incorporação de um tipo de busca como a descrita por Battelle às atuais estruturas de busca existentes. Entretanto, há quem garanta que é exatamente nesta direção que algumas ferramentas, Google na dianteira, estão trabalhando secretamente. Como sempre ocorre com a Internet, é esperar para ver! 